Revue Française de Civilisation Britannique

BRITANNIQUE

French Journal of British Studies

XVII-2 | 2012

Minorités, intégration en Grande-Bretagne et dans les pays du Commonwealth

\title{
Anti-Black Racism in British Popular Music (1880-1920)
}

Racisme anti-noir dans la musique populaire britannique (1880-1920)

John Mullen

\section{(2) OpenEdition}

\section{Journals}

Electronic version

URL: http://journals.openedition.org/rfcb/674

DOI: $10.4000 / \mathrm{rfcb} .674$

ISSN: $2429-4373$

Publisher

CRECIB - Centre de recherche et d'études en civilisation britannique

\section{Printed version}

Date of publication: 15 October 2012

Number of pages: $61-80$

ISBN: 2-911580-37-0

ISSN: 0248-9015

Electronic reference

John Mullen, « Anti-Black Racism in British Popular Music (1880-1920) », Revue Française de

Civilisation Britannique [Online], XVII-2 | 2012, Online since 15 March 2016, connection on 19 April 2019. URL : http://journals.openedition.org/rfcb/674 ; DOI : 10.4000/rfcb.674

This text was automatically generated on 19 April 2019

\section{c) (i) $(9)$}

Revue française de civilisation britannique est mis à disposition selon les termes de la licence Creative Commons Attribution - Pas d'Utilisation Commerciale - Pas de Modification 4.0 International. 


\section{Anti-Black Racism in British Popular Music (1880-1920)}

Racisme anti-noir dans la musique populaire britannique (1880-1920)

John Mullen

\section{Imperialist expansion and "scientific" racism}

1 The rapid expansion of the British Empire in the second half of the nineteenth century very much involved Africa and Africans. From the 1880s, war in Sudan confronted Charles Gordon, leading Egyptian and British forces, with the Sudanese revolt. White-led "loyal natives" were faced with "African barbarians" in the dominant English world view of the time. In 1884, the Berlin conference formalized the agreement made between European powers (with no African representatives present), to divide up the African continent between them. In 1893, the First Matabele war showed the dreadful superiority of the British army with its Maxim guns, against spear-throwing locals. ${ }^{1}$ And, at the very end of the century, the Boer war between Dutch-speaking and English-speaking settlers in South Africa involved, to say the least, a cruel indifference to the fate of indigenous Africans. ${ }^{2}$ If there is no reason to adopt a conspirationist view of racial stereotyping in popular culture, racist discourses and representations were undoubtedly useful to the imperial vision of the world. If Black people could be considered as inferior, incapable or childlike, the justification for the imperial mission would be much facilitated. The supposed inferiority of African peoples could also serve as a post-facto justification of British organization of the transatlantic slave trade. Finally, it may be considered that racism played a role of social stabilisation often commented on. As Pickering remarks, popular entertainment based on racial stereotyping:

[...] encouraged all social classes in Britain to think in racial categories and to rank those categories on the basis of allegedly innate inequality between races [...] this deflected attention away from class and gender divisions. ${ }^{3}$

Much has been written about the development of racist theories among Victorian intellectuals, theories sometimes referred to as "scientific racism". In his book The 
Mismeasure of Man, US science historian Stephen Jay Gould recounts the extreme reluctance of many nineteenth-century intellectuals to doubt the "obvious" superiority of the white man, even when faced with clear experimental evidence to the contrary. ${ }^{4}$ In 1863, James Hunt of the Anthropological Society of London posited that "negroes" were a separate species, and were irredeemably inferior to Whites. Professor Francis Galton's book Hereditary Genius, published in 1869, theorized that, if the ancient Athenians were even more intelligent than the modern English, the English were far superior to Africans. He also affirmed that a suitable role for the British in Africa would be to encourage the victory of the less inferior African tribes over the least "naturally gifted". In 1883 one of the few British writers who opposed racist ideas, philologist Robert Needham Cust, complained that "the vast majority of the educated public appears to have accepted at least some aspect of the new racial doctrine."

3 The link between racist theory and imperial practice was, moreover, fairly direct. Lord Lugard, Governor-General of Nigeria after 1914, wrote as late as 1922:

In character and temperament, the typical African of this race-type is a happy, thriftless, excitable person, lacking in self-control, discipline, and foresight, naturally courageous, and naturally courteous and polite, full of personal vanity, with little sense of veracity, fond of music and loving weapons as an oriental loves jewellery. His thoughts are concentrated on the events and feelings of the moment, and he suffers little from apprehension for the future, or grief for the past. His mind is far nearer to the animal world than that of the European or Asiatic, and exhibits something of the animal's placidity and want of desire to rise beyond the state he has reached. [...] In brief, the virtues and defects of this race-type are those of attractive children. ${ }^{5}$

\section{Popular imperialism and racism}

4 What then of the attitudes of ordinary people, those most likely to be enthusiastic participants in popular music events? In a period when most of the population do not have the right to vote, ${ }^{6}$ and the opinions of the masses are rarely thought worthy of recording, it is not easy to measure the influence of racist ideas outside the elite. Certainly, this period saw a sharp rise in popular imperialism, helped along by the rise of the mass-produced press and the development of the telegraph. In 1899, Rudyard Kipling published his poem on the "White Man's Burden" in a popular American magazine, and it became the symbol of the racist defence of imperialism, even if it did attract some criticism. ${ }^{7}$ The street parties in Britain during the Boer War showed the prevalence of popular imperialism. Then in 1904, Empire Day began to be widely celebrated, encouraged by the privately-funded Empire Day Movement. ${ }^{8}$ In particular, schoolchildren were mobilized to celebrate a consensual image of the Empire as a force for peace and civilization, and by 1910 the Church of England was publishing special collections of hymns for Empire Day. ${ }^{9}$

Of course, in all historical periods, the ceremonial activities of schoolchildren may tell us more about the values of headmasters than about those of children or their parents. As Thompson points out:

There are real problems in reading from imperial propaganda- however widespread or commercially successful-public acceptance or approval of the opinions therein expressed. ${ }^{10}$ 
We should not therefore be excessively definite - the most we can say is that there was a sizeable current of popular imperialism in the middle and working classes. Popular imperialism is not exactly the same as popular racism, even in this period when there was a very limited presence of non-white people in Britain, but they did tend to go together. Comic books and children's magazines about the "heroes" of the British Empire certainly did not hesitate to use racist stereotypes abundantly. Advertisements for everyday products blithely played on them, too. It will be unsurprising, then, to find a similar situation in popular entertainment. Thompson says of street ballads of the time

From the Indian mutiny (1857-8) through the confrontation with the Zulus (1879) to the struggle against the Boers (1899-1902), the empire's 'small wars' gave rise to a string of ballads that were very much alike in their emphasis on the savagery, brutality and treachery of non-European peoples, and the courage and bravery of those sent to fight in far-away locations. ${ }^{11}$

\section{The rise and transformation of the minstrel shows}

7 In late Victorian and Edwardian Britain, live entertainment and sheet music were the main focuses of popular song. If, by 1910, many ordinary people had been able, at the seaside or on a fairground, to listen to a few recordings on phonographs and similar machines, the everyday experience of listening to music was purely one of live performances: street singers, family sing-alongs at Christmas or musical evenings in a pub or in the parlour, barrel organ performances, and so on. England was a musical place: by 1914 there were over three million pianos in the country. Already, by the 1880s, the music hall was the dominant form of live musical entertainment, along with the pantomime (a sort of topical musical show produced in the Christmas season) and the much more expensively-ticketed musical comedy. But there was also a very particular form of evening show, a format which was built around racist caricaturing.

This was blackface minstrelsy. Where other forms of entertainment might include racial stereotypes, blackface minstrelsy, also generally known at the time as "nigger minstrelsy", was wholly built around the stereotyping of Africans or Black Americans. The minstrel show in its theatre version was an evening's entertainment performed by a troupe of white men blacked up to resemble caricatures of Black men: thick red or white lips, wigs of tightly curled hair and so on. This type of show was imported from the United States in the 1830s, but subsequently followed a separate development in Britain than on the American continent. By the 1850s in Britain, the minstrel show was very much stylized and structured. In the first part, a semi-circle of minstrels sang and played, and two clown minstrels, named Bones and Tambo, mocked the master of ceremonies, who perorated in pretentious and incorrectly used intellectual language. In the second part, a variety of circus-type acts and dancing acts were produced. The third part was mock heroic drama, in the style of, say, Shakespeare, produced in "nigger dialect" and overflowing with puns, malapropisms and exaggerated diction. A walk-around song completed the show. ${ }^{12}$

9 This form of entertainment became extremely popular, especially with new layers of clerks and shop workers with aspirations, and with the professional classes. More and more concentrated in the hands of a small number of companies with large amounts of capital, it experienced a veritable boom after 1870 . As one commentator writes: 
It caught the fancy of an amusement-starved public and was almost the only alternative to the doubtful humour of the music hall of the period. Minstrelsy was a form of family entertainment where husband and wife could take their children without fear of being asked embarrassing questions afterwards. ${ }^{13}$

It was thus considered as more "respectable" than the music hall, and certainly there was no risk of hearing sexual innuendo or rude jokes, or seeing women's legs, at the minstrel show. Gradually, the shows became more sophisticated and the costumes and sets more elaborate. Music-hall type songs or parlour ballads were added to the "plantation songs", and shows often now included virtuoso instrument playing, or dancing. Although racism was at the centre of the concept of the blackface minstrel show, it should not be assumed to be its only or even its principal attraction for the millions who flocked to buy tickets. The music and dancing was often of high quality, and the entertainment offered other pleasures. The minstrel was a clown figure who, at the same time as reinforcing negative stereotypes of black people, gave delight to the audience by mimicking and making ridiculous established elite figures, such as the politician or headmaster. Minstrelsy also developed a number of forms and structures which lived on in popular entertainment long after the minstrel show had died. Cross-talk comedy duos, where one "straight man" and one comic interact, were developed through minstrelsy, for example.

It is particularly important to underline that the social utility of the minstrel show was different in the United States and in Britain. In the USA, minstrelsy was one of many weapons to help keep down a large local minority population, and to cement white fellowship in the public mocking of the denigrated Other. The audience of the US minstrel show had everyday dealings with Black people and the show gave them images which had a practical effect in everyday living. For a long period, the US audience was made up essentially of working-class white men, whereas, as we have noted, the UK audience would include large numbers of middle-class professionals and their families. In the UK, the mocking of black people was the mocking of a distant denigrated Other: the majority of the audience had probably never met anybody who wasn't white. The racist stereotypes remained functional as a way of reinforcing popular imperialism, but impinged little on everyday living.

11 The minstrel shows' popularity generated a mass market for sheet music of the songs. A number of albums entirely made up of these songs were published, and many other albums would include a song of this type. As late as 1915, the People's Song Book, published in London, promised "32 favourite Scottish songs, 33 favourite English songs, 35 favourite Irish songs. 34 favourite Welsh songs (...) and 32 Nigger minstrel songs. All with music in sol-fa and staff notations, etc."14 One of the most popular minstrel troupes, the Mohawk Minstrels, published a regular magazine for a number of years. In each issue were a dozen or so songs. Interestingly, it seems that in each issue there was one "coon song" written in a caricature of Black American dialect. The rest of the magazine was made up of other types of song: love songs, jealousy songs, songs of joie de vivre, cute children, sick children dying, and dancing songs. There were also many "motto songs" delivering moral advice. The latter included such titles as "Do Not Speak the Angry Word", "Never Be Ashamed of Your Mother," "Think of the Lowly Ones" and "Do Not Nurse Your Anger" 


\section{The coon song and other offshoots of minstrelsy}

12 difficult to identify precisely the reasons for this. Certainly the rise of musical comedy as a more versatile evening of respectable entertainment was one factor: musical comedy aimed at the same market sector. Pretty dancers, sumptuous costumes and decor, the staged threat of loose morals and a spectacular wedding finale were the key attractions of this genre. While remaining more respectable than the music hall, the form was much more open than was the minstrel show to storylines of male-female relationships and "naughty" girls, the rise of which themes paralleled the very slow relaxation of Victorian morals. ${ }^{15}$

Blackface minstrel shows did not owe their decline to public protest over their racist content. We have found no examples at all of denunciations of blackface minstrelsy in Victorian and Edwardian Britain. ${ }^{16}$ If such denunciations existed, they must have been very much a minority affair. This is despite the fact that we know of severe criticism of minstrelsy in the US context from many decades earlier. Indeed, the great black abolitionist orator, Frederick Douglass, had declared as early as 1848 that blackface performers were "the filthy scum of white society, who stole from us a complexion denied to them by nature, in which to make money, and pander to the corrupt taste of their fellow white citizens." And in the 1850s, some in the US music industry had come to consider "minstrel dialect" as degrading. ${ }^{17}$

Even if a rejection of public racism was not one of the causes of the decline, it may well be that the abolition of slavery in the United States in the mid-1860s contributed to making the blackface stereotypes slowly appear out-dated. It does seem that the most violent racist content became considerably more muted as the genre moved into the twentieth century. The blackface minstrel continued for some decades to be widespread in many other forms, which developed in parallel with the theatre show. As a shorter seaside show, for example, blackface still had a long future - Uncle Mack's Minstrels, at Broadstairs near Brighton, played three shows a day from 1900 for almost fifty years. In town fairs or village fetes, the amateur minstrel troupe was omnipresent before the First World War. The street parade organized in support of the Crewe Memorial Cottage Hospital in 1907 "included no less than eight minstrel troupes from local workshops, with names like 'Original Golliwogs' and the 'Colombo Troupe of Dancing Darkies'."18

In particular, the blackface music-hall turn remained popular long after the decline of the full minstrel show. Dozens of greater and lesser artists tried their hand at it. Eugene Stratton, who died in 1918, G. H. Chirgwin, who died in 1922, and G. H. Elliott, who died in 1962, were the biggest stars. Elliott was billed as "The Chocolate-Coloured Coon" and Chirgwin as "The White-eyed Kaffir" (for reasons we shall see below). Chirgwin starred in the very first Royal Variety Command Performance in 1912, a show organized for the King, and an important milestone in the long campaign of music-hall proprietors to be accepted as respectable entertainment. The music hall chose, after 1880 , to portray one particular version of the Black stereotype, one suited to the one-man turn generally presented. As Pickering explains:

The coon was a particular extension of an earlier blackface stereotype, the uppity, socially pretentious, outlandishly attired nigger buck of countless songs. This urban dandy Jim figure contrasted with the plantation sambo. ${ }^{19}$ 


\section{Into the twentieth century}

In the minstrel show, there were only men on stage, but in the music-hall turn, after 1890, women or even children could be "negro imitators" or "negro delineators", as they were also called. Bessie Wentworth, who died in 1902, was one of the most successful, and May Henderson did blackface on the music-hall stage at least as late as $1927 .{ }^{20}$ In 1915 , the "youngest ever" negro imitator was presented at the music hall - a child of eight years old. ${ }^{21}$ The music-hall turn saw some development in the caricature and the stage use of it. This is particularly notable in the case of Chirgwin, billed as the "White eyed Kaffir". Chirgwin played in blackface make-up, but with a diamond over one eye which was madeup white. This adaptation, apparently of accidental origin, allowed him to make his stage persona more complex; one had the impression of the artist peering from behind the mask, therefore identified as artificial. "Chirgwin's persona was as much cockney as nigger" writes Michael Pickering, ${ }^{22}$ "and in this he contrasted with some other performers who wanted their nigger mask to be 'realistic'."

The "coon song" often faded gradually, in the twentieth century into the "Dixie song", a genre which could be presented by blackface or by other artists. These songs idealized a past in the South of the United States, in times supposed to be nobler and simpler. For the artists and their audiences, Dixie stood for a lost paradise which could just as easily have been located elsewhere. Indeed "Old Dixie could merge hazily into an equally vague concept of 'old England'"23 These Dixie songs were very popular during the First World War, in particular after the Dublin revolt of 1916 made songs about Ireland as a rural paradise more difficult to sell. We found at least twenty-five different ones sung in the music halls of the war years. They included titles such as the following:

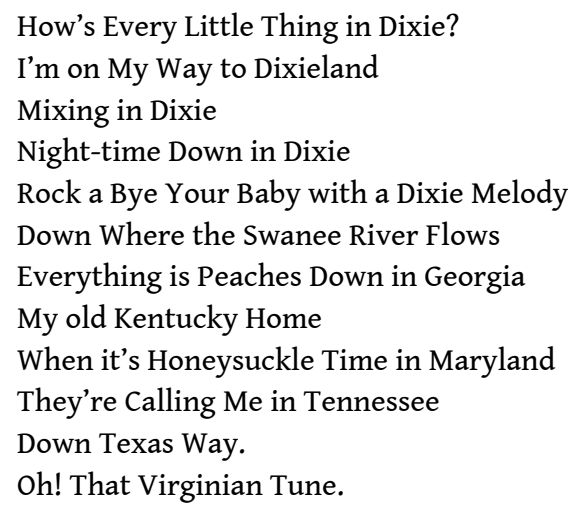

\section{The racist content in songs}

We are now going to look in more detail at the racist content of the songs in the period 1880-1920, though we have omitted some of the most deeply distasteful examples. In the twenty-first century, some aspects of racism are widely understood; in the period we are studying, this was not the case. As Pickering writes, Victorian racism "was a social phenomenon that did not know itself, and as such had not been publicly named," ${ }^{24}$ and this observation seems to us equally valid for the racism of the early twentieth century. It is thus a rather different phenomenon from twenty-first century racism in Britain. Racism today may be structural and institutionalized - as was shown by the Macpherson report

Revue Française de Civilisation Britannique, XVII-2 | 2012 
of 1999, and by the results of attempts to "promote racial equality" since this objective became compulsory for public bodies in 2000. Or it may be part of the programme of a minority, militant organization such as the British National Party or the English Defence League. However, although almost any member of an ethnic minority can explain that more subtle racist attitudes are widespread, it is difficult for us today to imagine the situation where the biological superiority of the "white race" was taken for granted across all social classes.

In the songs about "niggers" and "coons" from 1880 to 1920, the Black man and, less frequently, the black woman, are generally imagined as the mirror image, the polar opposite of the ideal white Victorian or Edwardian gentleman and lady. The first element to consider is the supposed physical characteristics of the black Other. The blackface mask was deep black ("racial mixing" was to remain invisible), and characterized by big eyes, big lips, very white teeth, and tightly curled hair. The audience immediately recognized the type and associated it with other characteristics they had read of or heard of, since racial stereotyping was widespread. Indeed, the description of the "typical negro" in the mass-circulation magazine The Boy's Own Paper in 1895, was not unusual at the time:

The arm is two inches longer in proportion than that of a Caucasian, and the hands hang level with the kneecaps; the facial angle is seventy as against eighty three, the brain weighs thirty five as against forty five; the skull is much thicker [...]there is no growth in intelligence once manhood is reached. ${ }^{25}$

In the songs from minstrel shows, we see many examples of grotesque physical characteristics. In the song "Happy Am de Boys Down Dere", we see the narrator's auntie, Aunt Deb, "has a mouth two acres wide". Some years later, Eugene Stratton's hit song "The Whistling Coon" presents his character as "an independent, free and easy, fat and greasy ham, with a cranium like a big baboon." ${ }^{26}$ A number of songs present the colour of the skin as a painful problem. The 1898 song ${ }^{27}$ "She's a Thoroughbred", as well as using a word "thoroughbred" normally reserved for animals, to refer to a black woman, boasts that she is not as black as some : "She's a thoroughbred, the best in town, she's not so dark, just a chocolate brown." The 1910 song "I'm Sorry You're a Coon" has a similar focus. The hair of the black Other is presented, in songs such as "You Must Have de Wool on de Top" as automatically hilarious. Typical is an 1898 song, "Dere's Something about Yer I like," which has the following chorus, sung by a young man to his girl:

You're not good looking, you're a big fat ugly coon

You're not so stylish for your clothes am out of tune

You are de blackest wench dat ever crossed de pike

Yet dere's something about yer I like.

21 A few songs fantasize about being able to "correct" the "defects" of black people. An 1894 song looks forward to the day "When They Straighten All the Coloured People's Hair," whereas the 1906 song "De Whitewashed Coon" imagines a story of a white coon, who is disliked by the other coons, because all the black girls prefer him.

\section{Happy, childlike, stupid...}

Moving onto psychological characteristics, the imaginary black people are first portrayed as childlike and full of fun, ("De Sun Am Shining All de Time" 1889), tremendously attached to their white masters and their life as slaves on the plantations, devastated 
when their master dies ("Ole Massa's Passed Away", "Massa's in De Cold Cold Ground"), delighted when the master comes home after a holiday ("Massa's Sent a Jellygram to Say He's Coming Home). They love their work, southern cooking, and singing in the evenings. Here are a few more song titles:

- Happy Little Sam 1874

- Nuffin' Hurts Me 1877

- I'm a Happy Darkey lad 1880

- The Laughing Darkie 1897

- Happy Am de Boys Down Here

- Happy Little Darkie 1899

- The Laughing Nigger Boy 1914

Only very rarely is the black man represented as menacing, as in "The Cannibal Nigger" in 1891, or "Li'l Cannibal Coon" in 1921. This presentation of the happy black slave did not prevent quite a number of minstrel shows from including scenes or even songs which opposed slavery. "The Flight of the Slave", "Chorus of Freed Slaves" and "Emancipation Day" are three examples. If the black Other was happy, he was also stupid. He would often speak in a caricature of Black American English, and one of the turns in each evening minstrel show would be a "stump speech" where an artist gave a pretentious delivery, filled with intellectual words incorrectly used or wrongly pronounced. Here is an example of the emphasis on stupidity, a piece entitled "The Nigger that Never Knew Nuffin at All:"

His name was Peter, he thought it was Sam

He thought a pig's head was a shoulder of lamb

And he blacked his boots with strawberry jam,

The nigger that never knew nuffin at all.

His Aunt Susannah disliked him so

For he always called her his Uncle Joe

And he thought his right thumb was his left big toe,

He was such a nigger noramus

The 1905 hit "The Silliest Coon in Town" and the 1913 number, "The Simple Nigger" paint a similar picture.

In addition to being stupid, he was lazy. An 1899 song explains: "I know a coon who never worked a day in all his life." The 1912 song "The Lazy Coon's Dream" follows a similar vein. One of Eugene Stratton's 1896 hits, "The Idler," presents a lazy Black narrator who is proud to be so: "I'm just about the idlest coon that ever shook a leg. Too idle for to work and too idle for to beg." The sing-along chorus continues:

I'm an I D L E R I'm an idler

I'm an I D L E R

I can take a drink all gay

But when it comes my turn to pay

I'm an I D L ER

The sing-along chorus allows the audience, as well as endorsing the stereotype, to borrow the mask of the idler and to enjoy celebrating being lazy at a time when hard work was a key social value. A similar phenomenon is seen in a fair number of music-hall songs.

We are not surprised to see innate dishonesty as another part of the Black caricature. "The Flyaway Coon" presents a Black man who eats in expensive restaurants and drinks champagne, but manages to disappear when the bill arrives. The narrator of "The Coster Coon" had to leave the United States and come to London because he had stolen a chicken, whereas the titles of the 1896 song "Cunning Little Coon" or the 1901 song "The 
Burglar Coon" speak for themselves. In some songs the nature of the Black man is a subject of "debate". The song "The Coon's Conscience" in 1908 examines the question of whether Blacks are responsible for their dishonesty, and suggests that they cannot help themselves. The "coon" brings back a dead chicken he had stolen from a parson, and explains himself in these words:

In my heart dere's a good man a-living and a bad man too.

Dey both start telling me what I'm to do.

Bad man says do what isn't right,

Den de good and the bad man quarrel in my heart

And keep me awake all night.

\section{The "ridiculous" black man} continues to whistle happily. This festive recounting of the black Other suffering is a key ingredient of racist humour throughout the centuries. Thus the 1902 song "Ten Little Niggers from Ohio" presents ten black men who all love the same woman. Although they know she will not want a black sweetheart, they are all determined to win her over. One buys a gun, and they fight until all are killed. The whole story is of course sung in a joyous and jaunty tone. In "The Nigger and the Bee", a lazy black man, who tries to steal honey from a beehive, gets attacked by swarms of bees. The black Other is above all presented as ridiculous. There is also however an even more
vicious undercurrent. In a number of songs the black man suffers violence. In "The
Whistling Coon" (1891), the black character has his head smashed by a brick, but A fair number of songs deal with the idea of a black man filling a prestigious role: a military major, a society gentleman and so on. In the racist atmosphere of the time, this is automatically funny. Titles such as the following are in this category:

- The Black Philosopher (1878)

- The Military Coon (1896)

- The Darky Aristocrat (1896)

- The Coon Drum Major (1899)

- The Phrenologist Coon (1901)

- Ma Coon's Got Lots of Money (1902)

- The Coon Ambassador (1903)

- The Society Nigger

- Ma Coon Am a Millionaire (1904)

- Oh! I Am a Darkie Beau (1911)

- If You Should See a Dandy Coon. (1911)

The 1899 song "I'se a lady" is exceptional in that it is sung by a blackface woman. A coloured woman declaring herself to be a lady is supposed to be amusing in itself. Three years previously, the song, "De Next President Am Gwine to Be a Coon," published both in Boston and London, laughs at the idea that the next US president will be a black man:

I tell yer Mr Johnson, if times keep growin' worse

De next president am gwine ter be a coon

When Bill he gets elected he's gwine to make things hum

He's gwine ter banish white folk ter the moon

There weren't be no more working

Jest only eat and bum

De next president am gwine ter be a coon. 
Cockney Coon" (c1899) tells of a Black man who lives in London:

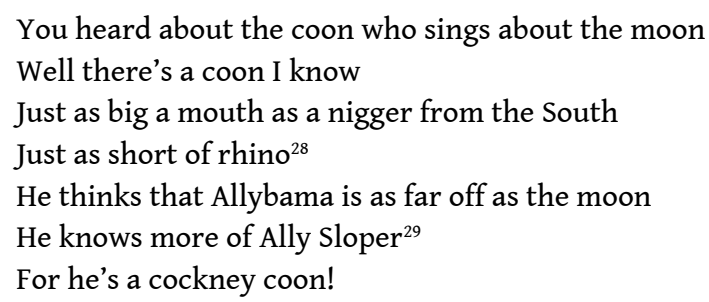

The emotive force of the song comes from the supposition that black people who are also cockneys are a hilarious impossibility. Here the black Other invades the home territory of the popular audience, in a publicly recounted nightmare, at which the white people laugh together to reassure themselves of its impossibility. Along the same lines is a song called "The Tipperary Coon". It tells of a Black man who falls in love with "an Irish girl, face fair, red hair." He goes to see his future father in law who:

Emptied first his whisky flask

Said "why the divil, may I ask

Don't you remove that ugly mask you brute?"

But when I told him t'was my face

Said he "Oh Bridget, don't disgrace

The bould McCarthy blood and race

This song manages to denigrate both the black man, and the "stupid Irishman", another traditional target of racist stereotyping in England. In racist imagination over the ages, the fact of black men becoming intimate with white women has always been a leitmotiv.

After this survey of the main elements of racist content, it is worth reflecting on the structure of the communication of these racist stereotypes. Black people are here denigrated on stage in front of a white audience enjoying one of their rare leisure evenings. The representation gains even more emotional force from the fact that the audience is seeing, or pretending to see, black people denigrating black people, rather than white people doing so. Finally, the tradition of collective sing-along choruses reinforces the emotional weight further. It may well be that the ideological effect on the mass audience is far greater than all the ministerial speeches about imperial policy.

It seems that the most vicious of the racist songs became much rarer after the 1900 s. When Chirgwin writes his memoirs in $1912^{30}$ he only mentions sentimental songs, not ones with an easily identifiable racist content. G. H. Elliott's later production is almost exclusively made up of nostalgic "Old Dixie" Songs, love songs and cheer-up songs, and they are not generally sung in mock dialect, though some songs still represent the "ridiculous" Black Other, such as the 1929 recording about a man who learns to yodel, and seems so strange in the evening sing-alongs among the "Darkies" on the plantation. Though the blackface minstrel could be seen on British television as late as the 1970s, the content had been watered down tremendously. Words like "coon" and "nigger" were no longer used, and the songs were cheer-up songs, Dixie songs and lovesick songs. The visual caricature however, has changed little. ${ }^{31}$

\section{“Positive" stereotypes}

We must not think, though, that blackface is only based around the political need to have a black Other. The stage Other is constructed, mostly subconsciously, by the artists and 
goes much deeper into the Victorian and Edwardian psyche than do the commands of British imperialism. Notably, the characteristics imagined in the black Other are not always negative. As Michael Pickering puts it "the Black low Other was both derided and desired." ${ }^{32}$ Victorian and Edwardian gender roles were complex, but very strict. Since almost all blackface represented black men, the rules about masculinity are the ones we must look at. The black Other is represented as being able to be and do those things which are forbidden to a respectable Victorian or Edwardian man. Therefore, he can ignore such dull virtues as thrift, hard work, and seriousness, and instead be lazy, playful, lighthearted and emotional.

The black man on stage is, then, portrayed as being much more sentimental, and attached to his children, than is the white man. So songs from the 1880s like "Baby Boy Has Passed Away" and "My Honey Baby Coon", in each of which a man mourns the death of his baby, would be extremely difficult to perform in that society with a white stage persona..$^{33}$ This despite the fact that the experience of having babies in the family die was widespread in all social classes. Other songs such as "De Nigger's Babbies" (1876) and "I'm the Father of a Little Black Coon" ("Enjoy yourselves with me. I'm as happy as can be - I'm the father of a little black coon.") show men celebrating their relationship with their children - in the former, the persona sings of how he loves to sing his children to sleep with his banjo.

The black-character-on-stage is also frequently represented as lovesick or jealous. Although readers today are very familiar with lovesick or jealous male narrators in popular songs, from Bing Crosby via Human League to The Streets, it is important to remember that this was practically unknown at this time. ${ }^{34}$ The white male lover narrator was almost always either completely in love (and planning to marry) a perfect woman, who was made to love him back, or married to a hopeless nag. The introduction of sentimental male narrators into popular song was not without its conflicts. During the Second World War, important sections of the BBC establishment opposed the broadcasting of melancholic "crooners" songs", seen as "anaemic", "debilitated" and "slushy in sentiment". The radio programme Sincerely Yours, presented by Vera Lynn, was criticized in parliament as " $a$ potential threat to the national fibre". ${ }^{35}$ The BBC was convinced that the jaunty and boisterous tone of First World War songs was still what was needed for national morale in the Second war.

This is then the reason why the lovesick and jealous roles are left to the imaginary black character. They are not generally meant to be comic, but moving, at the same time as distanced from the respectable white audience's gaze, although they may sometimes combine the portrayal of a desired sentimental other and a ridiculing of the suffering of the black man. These songs include the following:

- Every Nigger Had a Lady but Me 1895

- Don't Yer Trifle Wid Me, Honey 1896

- Now de Eyes I lubb'd Am Flown 1897

- Are You Gwine ter Kiss Yer Jacob?

- A Lovesick Nigger

- The Bachelor Coon's Lament ...

- There's One More Coon Who Has Lost His heart

- Why Don't Yer Lub Me, Honey? 1900

- The Only Coon Without a Gal 1905

- A Lovesick Coon 1911 
A final element of the desired Other involves the supposed capacity for spontaneity and musicality. Expressing emotion, in Victorian and Edwardian conceptions of respectability, was problematic, and this was one of the reasons for the cool reception the British establishment gave to Jazz music, when it arrived in Britain shortly before 1920. The black characters in minstrelsy and in coon songs are, then, presented as able to express themselves in frowned on but exciting ways. "Over and over again, Blacks are venerated for the emotional spontaneous music and at the same time reviled for its allegedly degenerative influence. ${ }^{36}$ This trope will of course continue to be present in racial stereotyping for many years afterwards.

\section{The Great War}

41 The arrival of the Great War in 1914 gave rise to a change in the British view of African peoples. They were now to be praised as noble allies and fighters for the Empire. Tom Clare's 1915 music-hall song "Once the Kaiser's Army" emphasized the "heroic" role of empire armies. This theme did not produce a large number of songs which mention black soldiers as such, but the 1915 song "John Bull's Little Khaki coon" is to be noted. The narrator is a black soldier, the title identifies him as childlike ("little"), and the lyrics include the following:

Germany has found that the colours won't run

No matter how you shoot

We always stand our ground

And John Bull's very proud of his little khaki coon

And the sing-along chorus is as follows:

I'm not a common darkie

That's why I'm dressed in khaki

One of the boys that helped to bear the brunt

We've been very very busy at the front

William thought he had us cornered

But we've made him change his tune

I'm an absent minded beggar

But everybody's proud of

John Bull's little khaki coon

As part of the imperial forces fighting "German barbarism", the African man has lost most of the traditional elements of his stereotype. He speaks in normal, grammatical English, and, importantly, as the narrator is the black man, the audience is asked to identify with him, and sing with his mask on, in the sing-along section. ${ }^{37}$ The paternalism of the song was not necessarily reserved for black peoples. The popular 1916 song "Well Done, Little Ones, Bravo Belgian Boys" demonstrates this, as do the 1914 hits "Good Luck, Little French Soldier Man" "Three Cheers for Little Belgium" and "Bravo, Little Belgium."

There had been at least one precedent for a Black soldier narrator - a song some fifteen years earlier: "Victoria's Black Hussars". ${ }^{38}$ Here are some of the lyrics:

Niggers want free trade to fight as well as whites

And so we've got a black brigade to put the world to rights

Though we're all black we won't turn back but fight till all is blue. 


\section{The Irish and the Jews}

Anti-Black racism is not the only form of racial stereotyping in the popular songs of the time. Both Irish and Jewish people were caricatured and mocked in song, and there is a link between the development of immigration in England and these songs. In both cases, the phenomenon differs from the case of anti-Black racism in the sense that the musichall audiences of the time would know and meet Irish and Jewish people in their everyday lives, and so the construction of the Other would fill different needs. In both cases, too, the desirable Other is mixed in with the denigrated Other. Considerable further work is needed on the articulation of racial stereotypes of the Irish and the Jewish and popular entertainment of the time.

\section{Conclusion}

We hope we have shown in this article the weight of racist stereotyping in popular song of this period, and its probable usefulness for the Empire project. The public denigration of the Black Other is, of course, not reducible to its racist content or imperial role. Public denigration of any Other is a form of general psychological compensation for popular audiences whose own denigration in the social economy of Victorian and Edwardian Britain was ferocious and continuous. It seemed to us important to pull out the specifically racist strands of popular entertainment in this period when it is turning into a veritable industry and has an ever wider influence on the way people see the world.

\section{APPENDIXES}

\section{Note on sources}

By far the majority of the songs quoted come from the vast, but very far from comprehensive, sheet music collections of the British Library in London. The songs there were generally published and sold as sheet music for piano and/or banjo, with the words to the songs included. Sometimes they were sold as albums - the "greatest hits" of a given year, or of a given artist or genre. Other song titles in our article were found in Michael Kilgarriff's encyclopaedia of the British music hall ${ }^{39}$, or are available from Windyridge, a small home-run company which has re-released on Compact Disc a few hundred songs transferred from the original phonograph cylinders or gramophone records of the time. In general, we have only mentioned US songs if they were also published in London, or if we had other evidence that they were sung on stage in Britain.

A few of the songs we have mentioned, though quite offensive, can be listened to or downloaded from the internet. A 1917 US version of "The Whistling Coon" can be heard 
here: [http://www.archive.org/details/

EdwardMeekerEmpireVaudevilleCompwithBillyMurray] (24/06/20011)

And a 1902 US version of "All coons look alike to me can be heard here: [http:// www.archive.org/details/ArthurCollinswithVessLOssman] (24/06/20011)

\section{Illustrations}

Newcomb's minstrels were an American group who had great success touring Britain.

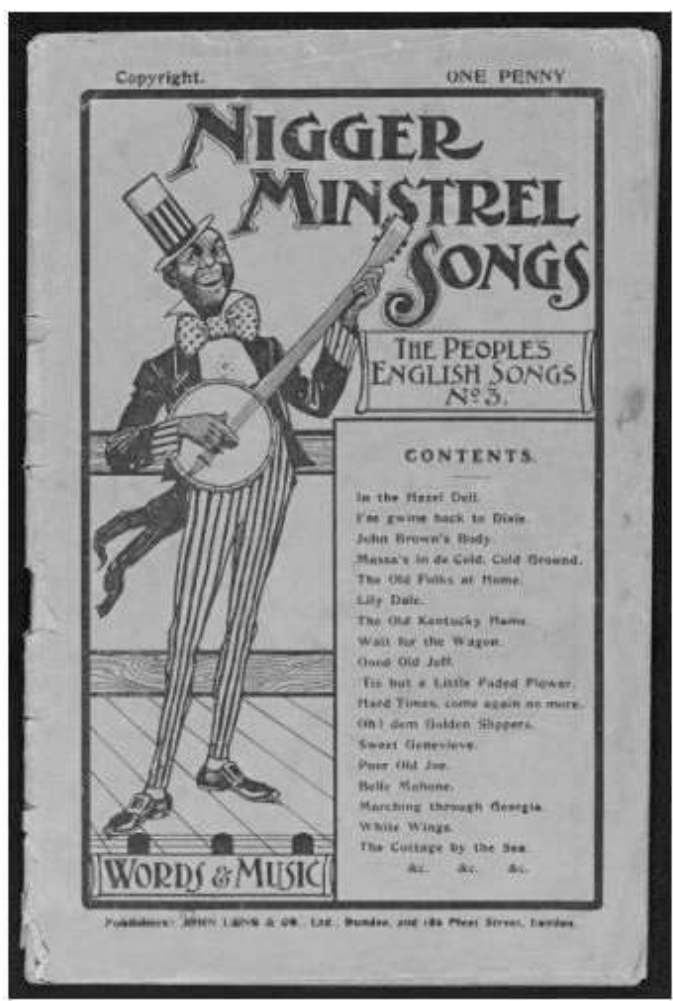


Uncle Mack's Minstrels still played at the seaside in Brighton in the 1930s.

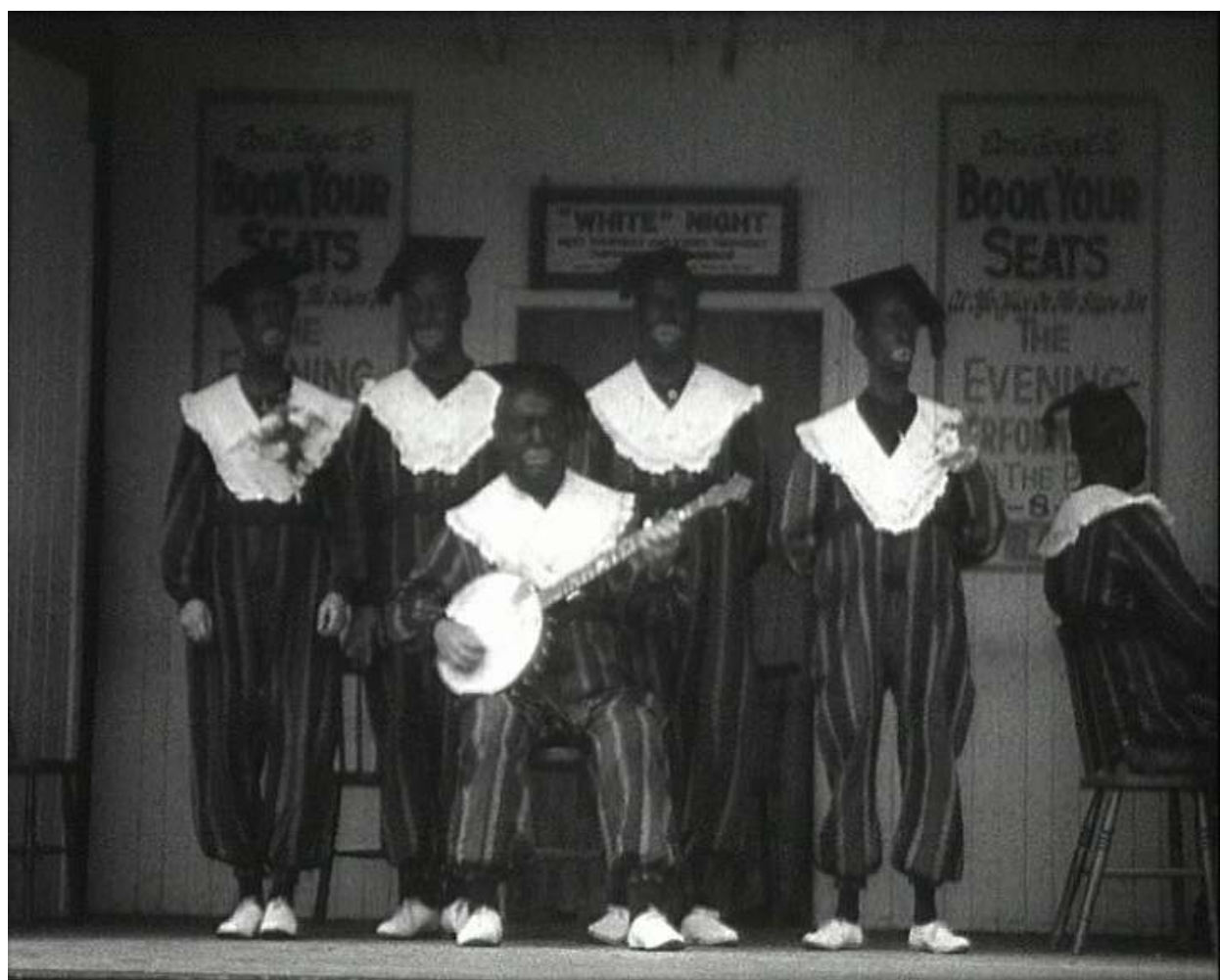

Adverts did not hesitate to use racism: an advert from 1907

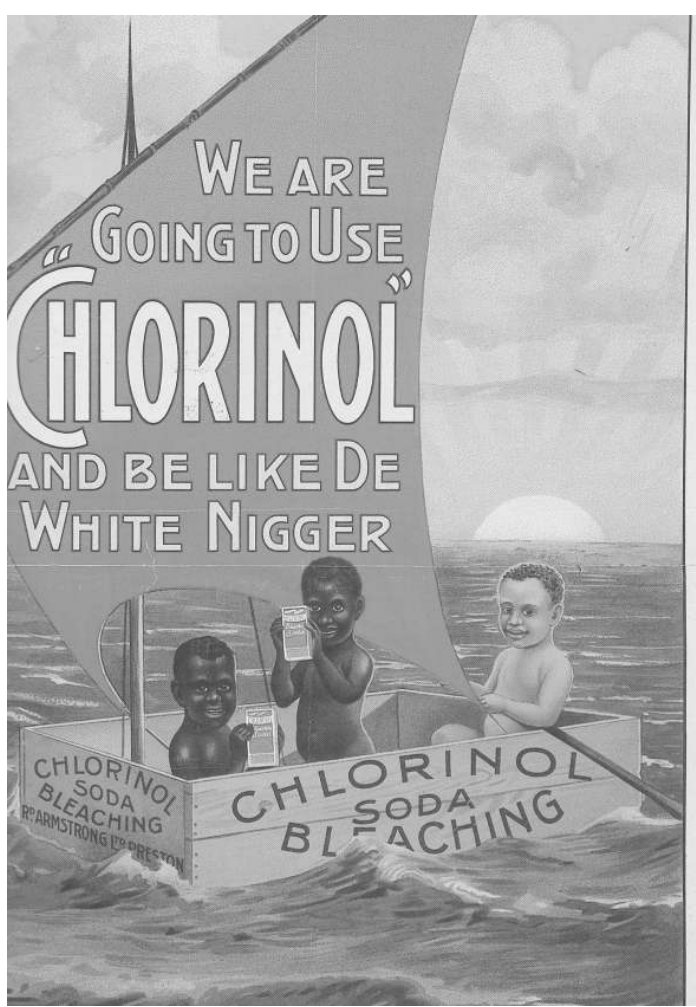


A racist caricature on a sheet music cover.

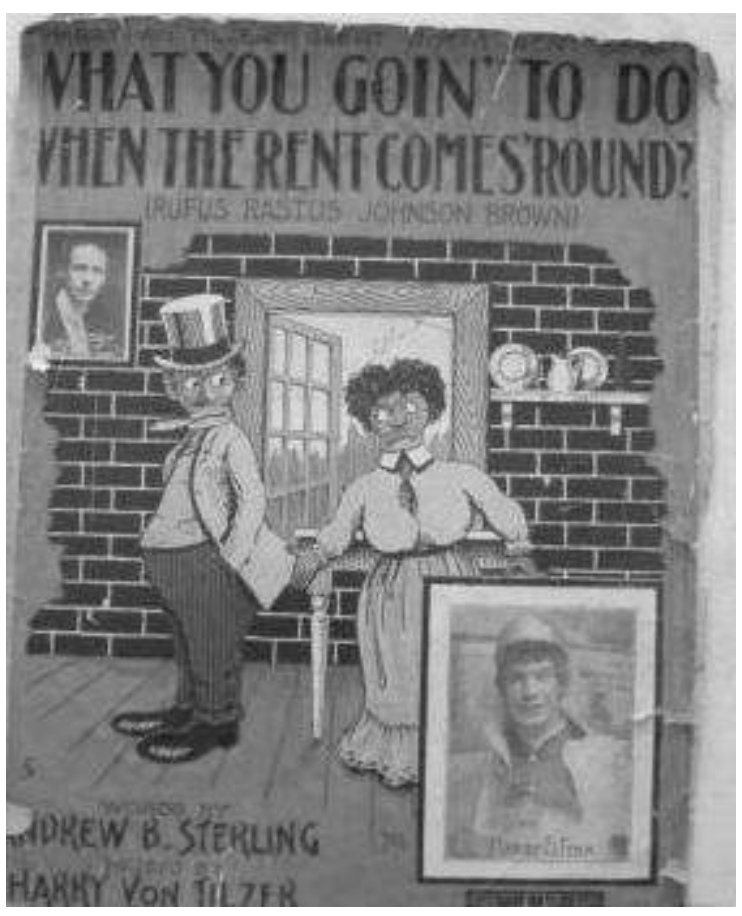

\section{G.H. Elliott (1884-1962)}

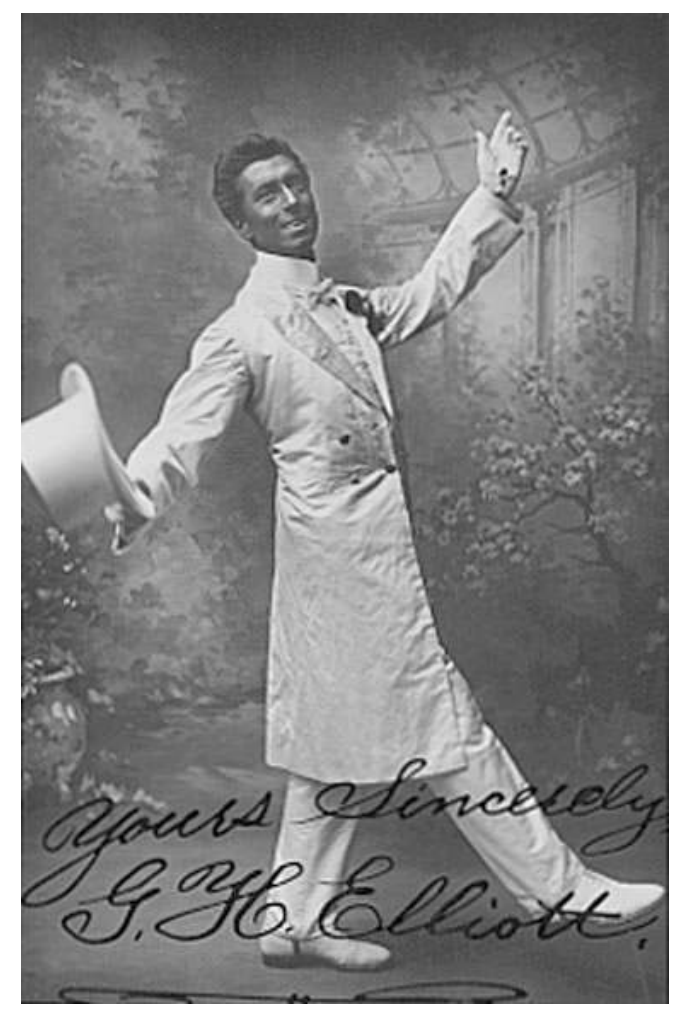


G H Chirgwin "The White-eyed Kaffir" adapted for his own purposes the blackface tradition, and mixed it in with the cockney persona.

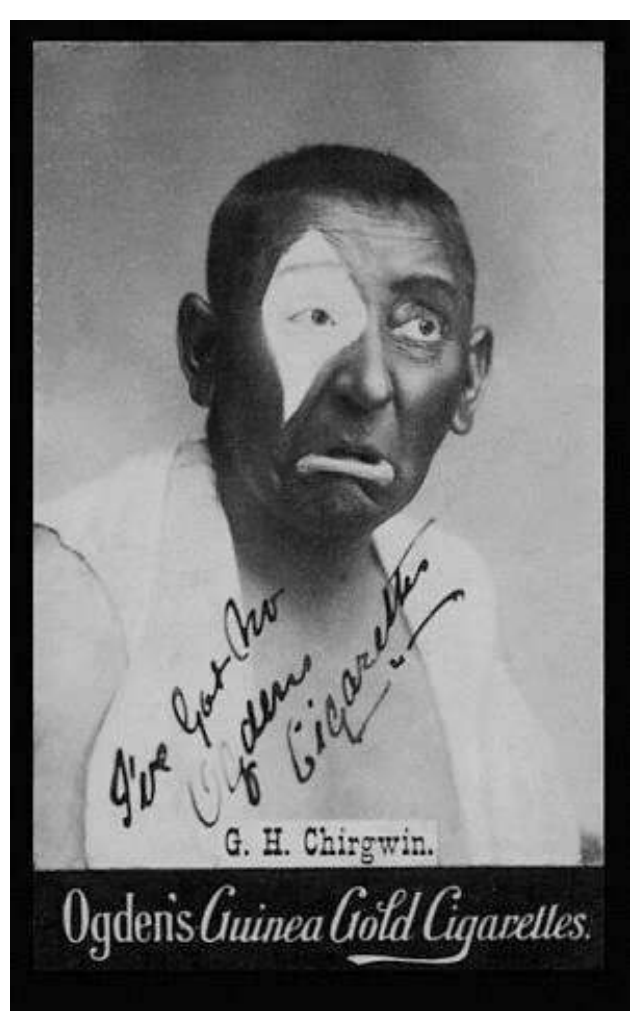

After 1890, some female "negro imitators" made a good living on the music-hall stage; here, May Henderson, who worked at least until 1927.

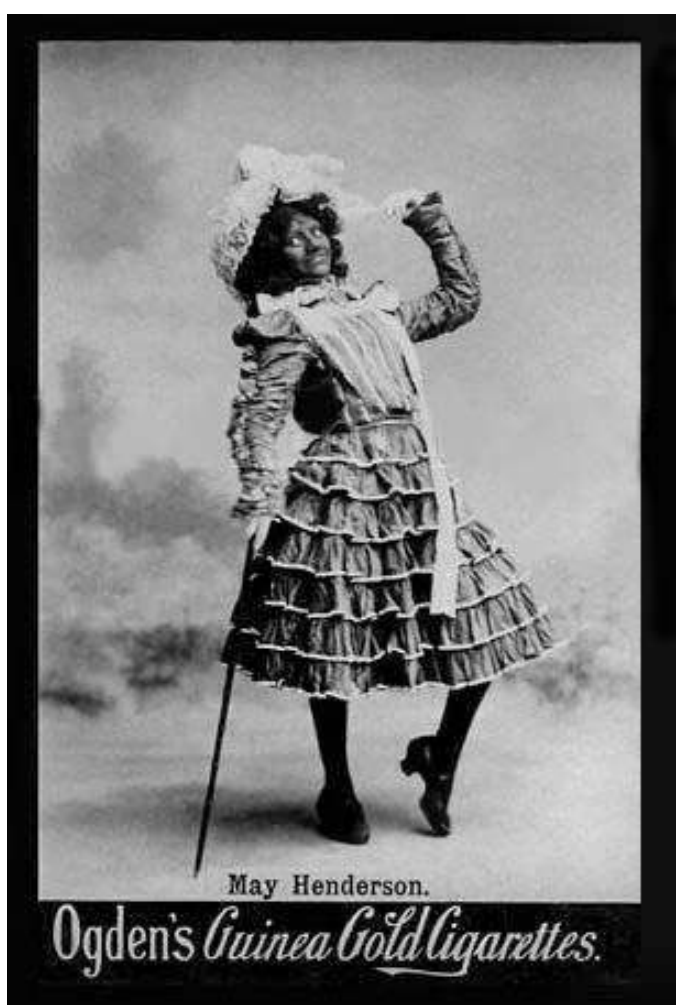

Revue Française de Civilisation Britannique, XVII-2 | 2012 


\section{A CD release today}

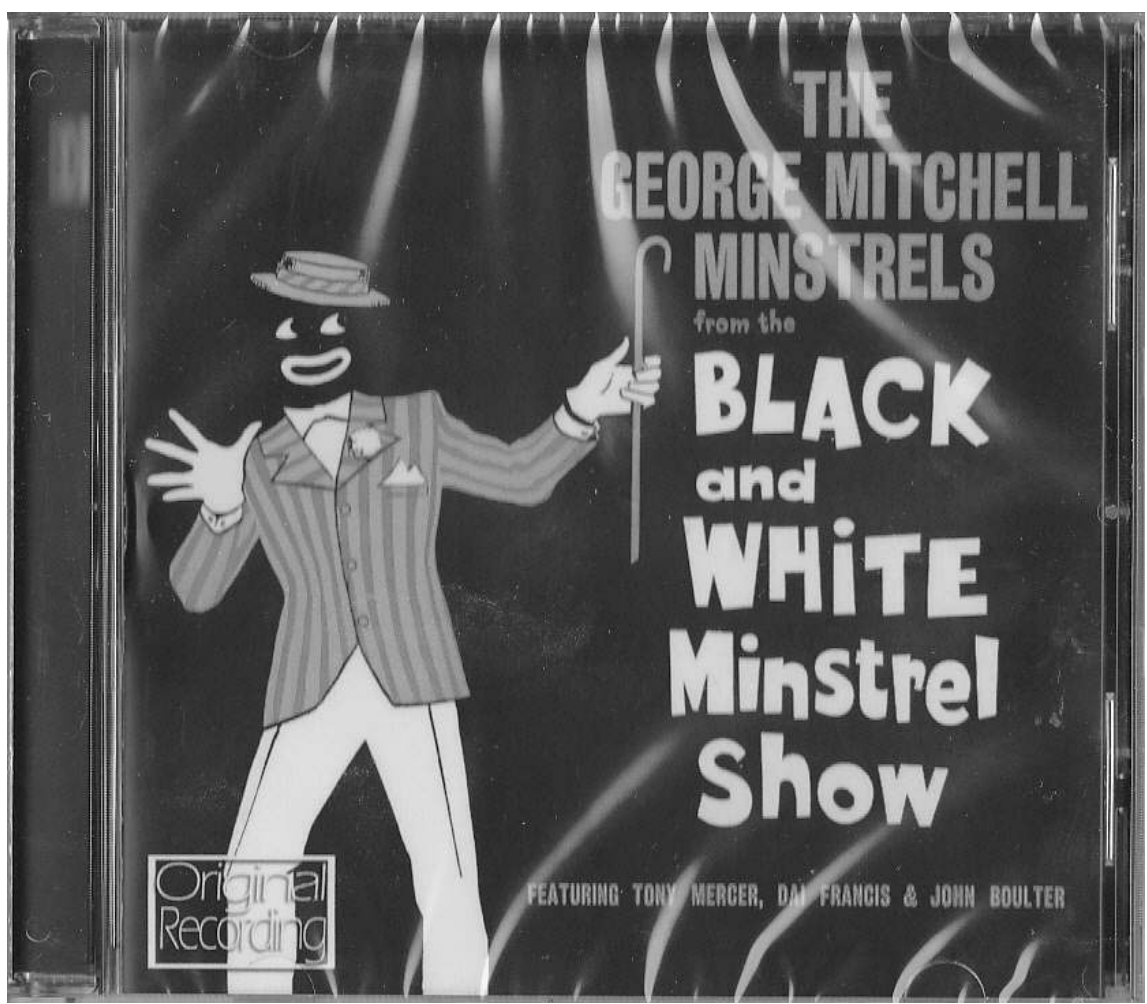

\section{NOTES}

1. Leading Hilaire Belloc to pen the aphorism "Whatever happens, we have got / The Maxim gun, and they have not."

2. Niall FERGUSON, Empire: How Britain Made the Modern World, Harmondsworth: Penguin, 2004, p. 278.

3. Michael PICKERING, Blackface Minstrelsy in Britain, Aldershot: Ashgate, 2008, p. 109.

4. Stephen J GOULD, The Mismeasure of Man, New York: Norton, 1981, passim.

5. F.J. LUGARD, The Dual Mandate in British Tropical Africa, s.l.: Blackwell, 1922, p. 70.

6. The Representation of the People Act 1918 would increase the electorate from 7.7 million people to 21.4 million, $43 \%$ of them women.

7. See for example Edmund MOREL, The Black Man's Burden, in Louis L. SNYDER, The Imperialism Reader, Princeton: Van Nostrand, 1962, pp. 163-164. It was first published in 1903.

8. One can view a fascinating film of a popular Empire Day celebration in the North West of England, at the following address http://www.colonialfilm.org.uk/node/461.

9. Bishop of Durham, Bishop of Ripon, et al., Hymns for Empire Day, London: Skeffington and Son, 1910.

10. Andrew THOMPSON, The Empire Strikes Back: the Impact of Imperialism on Britain from the MidNineteenth Century, London: Pearson, 2005, p. 39.

11. Ibid. p. 51.

12. PICKERING op. cit., pp $17 \mathrm{ff}$.

13. John ABBOTT, The Story of Francis, Day and Hunter, London: William Chappell, 1952, p. 9.

14. The Peoples Song Book, Dundee and London: John Leng and Company, 1915. 
15. Peter BAILEY, "Naughty but Nice: Musical Comedy and the Rhetoric of the Girl" in Michael R. BOOTH and Joel H. KAPLAN (Eds), The Edwardian Theatre: Essays on Performance and the Stage, Cambridge: Cambridge University Press, 1996.

16. Michael Pickering, the author of the only full-length academic study of blackface minstrelsy in Britain confirmed to us that he knew of no such denunciations in Britain.

17. Derek SCOTT, Sounds of the Metropolis: The 19th-Century Popular Music Revolution (in London, New York, Paris, and Vienna), Oxford: Oxford University Press, 2008, p. 52.

18. PICKERING op. cit., p. 87.

19. Ibid.p. 160.

20. The Encore, 19 July 1917.

21. The Performer, 18 February 1915.

22. PICKERING op. cit., p. 98.

23. Ibid.p. 133.

24. PICKERING op. cit., p. 117.

25. Quoted in PICKERING op. cit., p. 125.

26. This song was previously recorded in the US in 1891, by George W. Johnson, a Black American, often considered the first Black recording star in the USA.

27. We will often note the date of publication of the sheet music. This is not always possible: sheet music is not infrequently undated in this period. If the song was published in the United States and in Britain, we have used the British publication date. In addition, it is worth remembering that some of the more popular songs will be sung on stage for periods of thirty years or more.

28. A slang word for "money".

29. A very popular British comic strip character, first published in 1867.

30. G. H. CHIRGWIN, Chirgwin's Chirrup: Being the Life and Reminiscences of George Chirgwin, the 'White Eyed Musical Kaffir', London: J. and J. Bennett, 1912.

31. Conflicts concerning blackface continue into the twenty first century. An Australian TV show which presented a blackface sketch by "The Jackson Jive", in 2009, caused considerable international uproar. Sydney Morning Herald, 8 October 2009.

32. PICKERING op. cit., p. 140.

33. It is not only the Victorian or Edwardian gentleman who cannot gush over his children - a famous 1915 music-hall song "A Little Bit of Cucumber" shows a "typical" working class man who cannot recall exactly how many children he actually has.

34. Although more common in the more up-market operettes of Gilbert and Sullivan.

35. Siân NICHOLAS “The People's Radio: the BBC and its Audience 1939-1945” in Nick HAYES and Jeff HILL (Dirs..), 'Millions Like Us?' British Culture in the Second World War, Liverpool: Liverpool University Press, 1999, p. 82.

36. PICKERING op. cit., p. 131.

37. Another song, from the previous year, "Our Boys in the Army" mentions Indian soldiers in a positive light: "The hindoos with their knives

Are offering up their lives For the honour of the empire's glorious name!"

38. Auckland Star 10 November 1880

39. Michael KILGARRIFF, Sing Us one of the Old Songs - a Guide to Popular Song 1860 - 1920, Oxfor: Oxford University Press, 1999. 


\section{ABSTRACTS}

The rapid expansion of the British Empire in the second half of the XIX ${ }^{\text {th }}$ century was accompanied by a rise in the diffusion and the legitimacy of racist ideas in Britain. Intellectuals wrote of the "scientific" differences between the races, and racial hierarchies were generally accepted by educated people. What of the uneducated? Comic books and children's magazines about the "heroes" of the British Empire certainly did not hesitate to use racist stereotypes abundantly. Popular racism against Black people served to legitimize the imperial project, but for most of this period was little aimed at a visible ethnic minority in Britain. Our article will aim at analysing the racist content of popular music in this period - both that of the extremely popular "minstrel shows", where white performers disguised themselves as stereotypical black slaves for the purposes of entertainment, and the "coon songs" which were common in the music halls. We will trace the depiction of the Black Other as the mirror image of the Victorian and Edwardian respectable gentleman and lady, and how, while generally denigrated, the Black persona could also be desired or envied.

L'expansion rapide de l'empire britannique durant la deuxième moitié du XIX ${ }^{\mathrm{e}}$ siècle fut accompagnée par une généralisation et une légitimation des idées racistes au Royaume-Uni. Des intellectuels discouraient sur les différences "établies par la science" entre les races, et une hiérarchie raciale était généralement acceptée par les gens instruits. Que dire du peuple non instruit? On constate que les bandes dessinées et les revues pour enfants, qui racontaient les aventures des héros impériaux, n'hésitaient pas à se servir abondamment de stéréotypes racistes et que les publicités de l'époque en faisaient autant. Le racisme populaire envers les Noirs contribuait à légitimer le projet impérial, mais, pour l'essentiel, durant cette période, ne visait pas une minorité ethnique visible en Angleterre. Notre article compte analyser le contenu raciste de la musique populaire entre 1880 et 1920, à la fois dans les spectacles des "blackface minstrels", lors desquels des hommes blancs se déguisaient en caricatures d'esclaves noirs pour divertir leur public, et dans les "chansons de nègre" très courantes dans les music-halls britanniques de l'époque. Nous retracerons la représentation du Noir, qui est présenté comme une image en miroir de la personne respectable victorienne ou édouardienne. Nous verrons aussi comment le Noir, l'Autre dénigré, pouvait aussi être envié ou désiré.

\section{AUTHOR}

\section{JOHN MULLEN}

John Mullen est Maître de conférences à l'Université Paris-Est Créteil. Il a fait sa thèse de doctorat sur le syndicalisme des fonctionnaires en Grande-Bretagne sous les gouvernements conservateurs de Margaret Thatcher. Depuis lors, il a publié une série d'articles sur le syndicalisme, mais a commencé, il y a cinq ans, des recherches sur la musique populaire britannique. Il prépare un ouvrage sur la musique populaire en Grande-Bretagne pendant la Première Guerre Mondiale. 